\title{
Pengaruh Investasi, Tenaga Kerja Dan Pengeluaran Pemerintah Terhadap Pertumbuhan Ekonomi di Provinsi Jawa Tengah
}

\author{
Bambang Setijawan, Nurul Anwar, Suharno \\ Fakultas Ekonomi dan Bisnis \\ Universitas Jenderal Soedirman \\ Email : bambangsetijawanse@gmail.com
}

\begin{abstract}
The average economic growth of Central Java Province is still low and it is in the fourth lowest rank of the six provinces in Java. This study aims to analyze the effect of investment, labor and government spending on economic growth in Central Java Province for the period 2014 - 2019. The data analysis technique used is multiple linear regression with a panel data approach. The results show that investment, labor and government spending have a positive and significant effect on economic growth in Central Java Province in 2014 - 2019. The implications of this study are 1) retaining incoming investors by providing services in accordance with the development of their respective needs and providing services. incentives so that investors feel comfortable investing their capital and attracting potential new investors to be willing to open a business in Central Java Province 2) increase employment returns, hold apprenticeship projects for prospective workers, improve workforce welfare, and improve the quality of the workforce so that labor productivity employment will increase 3) increase and maximize the allocation of government expenditure funds for potential sectors.
\end{abstract}

Keywords: Investment, Labor, Government Expenditure and Economic Growth.

\section{Pendahuluan}

Pembangunan ekonomi nasional dikatakan berhasil yaitu dilihat dari pertumbuhan ekonomi. Pertumbuhan ekonomi selalu menjadi problem pada setiap negara/wilayah. Pertumbuhan ekonomi menjadi tolok ukur penting dalam menganalisis sejauh mana perkembangan pembangunan ekonomi di wilayah tersebut. Pertumbuhan ekonomi merupakan kenaikan kapasitas produksi dalam perokonomian yang tercermin pada pendapatan nasional (Ernita et al. 2013). Menurut pengertiannya pertumbuhan ekonomi diartikan sebagai kenaikan GDP di suatu wilayah tanpa melihat apakah terjadi perubahan struktur ekonomi atau tidak (Ichvani \& Sasana, 2019). Berikut pertumbuhan ekonomi berdasarkan Produk Domestik Regional Bruto Atas Harga Berlaku 6 provinsi di Pulau Jawa Tahun 2015-2019.

Tabel 1

Pertumbuhan PDRB Provinsi di Pulau Jawa Atas Dasar Harga Berlaku Tahun 2015-2019 (Persen)

\begin{tabular}{llrrrrrr}
\hline No & \multicolumn{1}{c}{ Provinsi } & $\mathbf{2 0 1 5}$ & $\mathbf{2 0 1 6}$ & $\mathbf{2 0 1 7}$ & $\mathbf{2 0 1 8}$ & $\mathbf{2 0 1 9}$ & Rata - rata \\
\hline 1 & DKI Jakarta & 17,07 & 17,11 & 17,21 & 17,31 & 17,56 & 17,25 \\
2 & Jawa Timur & 14,52 & 14,70 & 14,65 & 14,61 & 14,62 & 14,62 \\
3 & Jawa Barat & 13,09 & 13,10 & 13,01 & 13,09 & 13,24 & 13,10 \\
4 & Jawa Tengah & 8,68 & 8,61 & 8,53 & 8,47 & 8,49 & 8,55 \\
5 & Banten & 4,11 & 4,10 & 4,10 & 4,10 & 4,12 & 4,10 \\
6 & DI Yogyakarta & 0,87 & 0,87 & 0,87 & 0,87 & 0,88 & 0,87 \\
\hline
\end{tabular}

Sumber: BPS Tahun $2015-2019$

Tabel 1 terlihat bahwa Provinsi Jawa Tengah menduduki peringkat keempat terendah sedangkan Provinsi DKI Jakarta masih menjadi Provinsi dengan laju pertumbuhan ekonomi paling tinggi di Pulau Jawa, diikuti oleh Jawa Timur, Jawa Barat, Jawa Tengah, Banten dan DI Yogyakarta. Naik turunnya pertumbuhan ekonomi disuatu wilayah dapat dipengaruhi oleh beberapa faktor, salah satunya yaitu Investasi. Menurut Nasution (2020) investasi adalah pembelanjaan modal yang digunakan untuk membeli perlengapan untuk tujuan menambah kapasitas produksi barang ataupun jasa. Investasi menurut jenisnya dibagi menjadi dua, yaitu investasi yang berasal dari pemerintah dan investasi yang berasal dari pihak swasta. Investasi pemerintah merupakan penanaman modal yang dilakukan oleh pihak pemerintahan setempat, sedangkan investasi swasta merupakan penanaman modal yang dilakukan oleh pihak swasta ataupun dilakukan oleh publik (Nasution, 2020).

Investasi merupakan salah satu unsur yang penting dalam mendongkrak perekonomian. Namun besarnya investasi tidak serta merta membuat pertumbuhan ekonomi menjadi cepat, tetapi bagaimana pengelolaan investasi itu sendiri. Beberapa penelitian terdahulu yang menganalisis pengaruh investasi terhadap pertumbuhan ekonomi telah banyak dilakukan, diantaranya Chidoko (2015), Rabnawas (2015), Williams, et al (2017), Prasetyawan, et al (20117), Ningsih, et al (2018), Tasrif, et al (2019) dan Hardiyanti, et al (2020) menemukan bahwa investasi berpengaruh signifikan positif terhadap pertumbuhan ekonomi. Namun demikian, beda halnya temuan Bado (2016), Bakari (2017) 
dan Astuti, et al (2017) yang menemukan bahwa investasi berpengaruh signifikan negatif terhadap pertumbuhan ekonomi. Selain investasi faktor yang dapat berpengaruh terhadap pertumbuhan ekonomi adalah tenaga kerja. Menurut Pramono, (2014) tenaga keja merupakan penduduk yang berusia 15 - 64 tahun yang mau dan mampu memproduksi barang ataupun jasa ketika ada pemintaan. Tenaga kerja meupakan unsur yang penting dalam mendorong pertumbuhan ekonomi. Beberapa penelitian terdahulu mengenai pegaruh tenaga kerja terhadap petumbuhan ekonomi telah banyak dilakukan, dinataranya oleh Sari, et al (2016), Williams, et al (2017), Rezki, et al (2018), Primalasari, et al (2019), dan Tasrif, et al (2019) yang menemukan bahwa tenaga kerja berpengaruh signifikan positi terhadap pertumbuhan ekonomi. Namun demikian, berbeda halnya dengan temuan Makodompis, et al (2014), Subiyanto (2016), Ningsih \& Sari (2018) dan Hardiyanti (2020) menemukan bahwa tenaga kerja berpengaruh signifikan negatif terhadap pertumbuhan ekonomi.

Faktor selanjutnya yang dapat mempengaruhi pertumbuhan ekonomi ialah pengeluaran pemerintah. Menurut Kamba et al., (2021) pengeluaran pemerintah adalah tindakan yang dilakukan oleh pemerintah guna mengatur perekonomian dengan menentukan besarnya pengeluaran dan pendapatan pemerintah. Studi empiris yang dilakukan Sari, et al (2016), Minzil, et al (2017, Rezki, et al (2018), Ichvani \& sasana (2019) dan Nasution, (2020) menemukan bahwa pengeluaran pemerintah berpengaruh signifikan positif terhadap pertumbuhan ekonomi. Hasil yang berbeda ditunjukkan oleh penelitian yang dilakukan Zamhuri (2016), Williams, et al (2017) dan Primalasari, et al (2019) yang menunjukkan hasil bahwa pengeluaran pemeintah berpengaruh signifikan negatif terhadap pertumbuhan ekonomi. Perbedaan penelitian ini dengan penelitian sebelumnya yaitu dimana pada penelitian ini peneliti akan meneliti pengaruh investasi, tenaga kerja dan pengeluaran pemerintah terhadap pertumbuhan ekonomi di Provinsi Jawa Tengah dengan menggunakan periode penelitian yang lebih lama yaitu yaitu 6 tahun seperti saran dari penelitian yang dilakukan Nasution (2020) yang menyarankan untuk menggunakan periode penelitian yang lebih dari 5 tahun karena menurutnya periode tahun penelitian sangat berpengaruh terhadap data penelitian.

\section{Tinjauan Pustaka \\ Pertumbuhan Ekonomi}

Pertumbuhan ekonomi merupakan suatu proses dari peningkatan output perkapita suatu wilayah dengan jangka waktu yang panjang (Wulansari et al., 2018). Menurut Primalasari, (2019) pertumbuhan ekonomi dapat juga didefinisikan perkembangan dari kegiatan suatu perekonomian yang mengakibatkan kegiatan produski barang atau jasa serta kesejahteraan penduduk meningkat. Sementara itu, pertumbuhan ekonomi bisa diartikan perkembangan dari kesejahteraan masyrakat yang kemudian diukur dari besar atau kecilnya pertumbuhan domestik regional bruto (Purnamasari, Rostin, \& Ernawati, 2017). Beberapa teori mengenai pertumbuhan ekonomi dari masa ke masa terus berkembang. Berikut ini teori-teori menurut para ahli (Ichvani \& Sasana, 2019):

1. Teori Ekonomi Klasik

Teori ekonomi klasik merupakan teori yang muncul dan dikembangkan mulai pada abad 17. Adam Smith dan David Ricardo merupakan tokoh yang snagat penting pada era ekonomi klasik. Menurut teori Adam Smith pertumbuhan output dan penduduk adalah dua aspek utama dalam mendorong pertumbuhan ekonomi. Emas dan perak yang dimiliki oleh suatu wilayah bukan lagi menjadi gambaran kekayaan negara tersebut. Menurutnya kekayaan suatu pemerintah dapat dibentuk dengan dua cara yaitu keterampilan dan efisiensi dari para tenaga kerja.

2. Teori Ekonomi Neo Klasik

Teori pertumbuhan ekonomi neo klasik dikembangkan oleh Robert Sollow dan Trevor Swan. Teori neo klasik berpendapat bahwa pertumbuhan ekonomi bersumber pada penambahan dan perkembangan faktor-faktor yang mempengaruhi penawaran agregat. Teori pertumbuhan ini menekankan bahwa perkembangan factor-faktor produksi dan kemajuan teknologi merupakan faktor penentu dalam pertumbuhan ekonomi. Fungsi produksi bersifat constant return to scale sehingga output akan meningkat dengan proporsi yang sama apabila kapital dan tenaga kerja digandakan dan input-input yang baru digunakan sepenting input yang telah ada. Input selain kapital, tenaga kerja, dan pengetahuan diasumsikan tidak penting.

3. Teori Harrod-Domar

Teori ini memiliki tujuan menjelaskan kondisi yang perlu dilaksanakan agar perekonomian mencapai keadaan yang baik dengan keadaan yang stabil pada jangka waktu panjang. Pada analisis dua sektor, agar pertumbuhan berada di masa yang baik dengan jangka waktu panjang, investasi harus benar-benar dalam keadaan yang terus meningkat. Untuk meningkatkan pengeluaran yang agregat juga diperlukan adanaya investasi tamabahan. Jadi jika investasi I, maka ditahun berikutnya harus ditingkatkan $\mathrm{I}+\Delta \mathrm{I}$ sesuai dengan teori hipotesis persinyalan (Signaling Hypothesis Teory).

4. Teori Ekonomi Endogen

Pada teori endogen menyatakan bahwa beberapa faktor yang mempengaruhi pertumbuhan ekonomi bukan hanya kapital dan tenaga kerja, namun ada juga faktor teknologi, bahan baku dan material serta kewirausahaan. Teori ini 
juga menganggap bahwa pertumbuhan mempengaruhi penyediaan infrastuktur, politik, kebijakan pemerintah, peraturan serta hukum.

Produk Domestik Regioanl Bruto (PDRB) merupakan indikator untuk melihat pertumbuhan ekonomi disuatu daerah/wilayah. Terdapat dua jenis Produk Domestik Regional Bruto (PDRB) yaitu Produk Domestik Regional Bruto (PDRB) atas dasar harga konstan, yaitu menggambarkan bagaiamna jumlah nilai tambah dan usaha dengan menjadikan satu tahun sebagai tahun dasar yang dihitung dengan harga berlaku. Dan Produk Domestik Regional Bruto (PDRB) atas harga berlaku, yaitu menggambarkan bagaimana nilai tambah dari kegiatan ekonomi yang dihitung dengan harga tahun berajalan baik berasal dari barang ataupun jasa.

\section{Investasi}

Investasi adalah kegiatan yang dilakukan oleh suatu pihak, yaitu baik pihak pibadi atau berbadan hukum dengan tujuan mempertahankan nilai modal yang dimiliki (Pangiuk, 2017). Nasution (2020) mendefiniskan investasi sebagai pengeluaran atau perbelanjaan untuk penanam modal atau untuk perusahaan guna membeli barang-barang atau perlengkapan dengan tujuan untuk menambah kapasitas kemampuan produksi barang maupun jasa yang tersedia dalam bidang perekonomian. Berdasarkan jenisnya investasi dibagi menjadi dua, pertama investasi pemerintah, merupakan penanaman modal yang dilakukan oleh pemerintah daerah ataupun pusat. Kedua investasi swasta, merupakan penanaman modal yang dilakukan oleh swasta nasional yang biasa disebut Penanaman Modal Dalam Negeri (PMDN) dan penanaman modal yang dilakukan oleh swasta asing atau yang biasa disebut Penanaman Modal Asing (PMA). Investasi yang dialokasikan untuk suatu wilayah akan menambah stok modal dalam negeri, mempercepat perekonomian, menambah lapangan pekerjaan, meningkatkan taraf hidup masyarkat dan dapat meningkatkan pemdapatan di wilayah tersebut (Sukirno, 2013). Apabila arus investasi masuk ke suatu negara dan berlangsung terus menerus dnegan jangka waktu yang panjang serta didukung perekonomian dengan daya saing yang tinggi, maka nantinya akan meningkatkan investasi melalui peningkatan stok perkapita. Peningkatan stok kapita nantinya akan meningkakan kemampuan masyarakat dalam menghasilkan output produksi dan menambah aktivitas perekonomian daerah tersebut (Mukhamad, 2014).

\section{Tenaga Kerja}

Tenaga kerja secara garis besar dibagi dua, yaitu tenaga kerja dan bukan tenaga kerja. Tenaga kerja merupakan penduduk yang masuk usia kerja yaitu berusia 15 - 64 tahun (Pramono, 2014). Batasan usia yang dianut oleh Indonesia adalah usia dasar 10 tahun, tanpa batasan usia maksimum. Jadi setiap orang atau penduduk yang berusia lebih dari 10 tahun termasuk tenaga kerja. Tenaga kerja merupakan sumber daya yang penting guna mendorong pertumbuhan ekonomi. Upah menjadi sebuah nilai untuk tenaga kerja. Tingkat upah yang tinggi diikuti dengan kualitas tenaga kerja yang tinggi pula, dan juga seblaiknya. Dengan banyaknya tenaga kerja yang berkualitas maka akan menghasilkan output produksi yang lebih banyak sehingga nantinya akan mendorong pertumbuhan ekonomi (Dwiningwarni, 2017).

\section{Pengeluaran Pemerintah}

Pengeluaran pemerintah dapat menambah kekuatan dan fleksibilitas ekonomi di kemudian hari. Pengeluaran pemeritah juga nantinya dapat memberikan kesejahteraan untuk masyarakat. Selain itu pengeluaran pemerintah juga merupakan salah satu penyedia lapangan pekerjaan dan penyebaran tenaga kerja yang luas (Darwin \& Hardilawati, 2018). Pengeluaran pemerintah memiliki tujuan yaitu menstabilkan harga dan tingkat output, membuka lapangan kerja yang lebih luas dan meningkatkan perekonomian (Nasution, 2020). Belanja pemerintah dapat mencerminkan strategi yang dilakukan oleh pemerintah.

\section{Metode}

Jenis peneltian ini adalah kuantitatif. Peneltian kuantitatif dapat diartikan sebagai penelitian yang digunakan untuk meneliti jenis populasi dan sampel tertentu. Dalam penelitian ini populasi yang digunakan yaitu seluruh Kabupaten/Kota di wilayah Jawa Tengah yang berjumlah total ada 35 Kabupaten/Kota. Variabel yang digunakan yaitu variabel dependen $(\mathrm{Y})$ dan variabel independen $(\mathrm{X})$. Pertumbuhan Ekonomi $(\mathrm{Y})$ sebagai variabel dependen dan Investasi (X1), Tenaga Kerja (X2), Pengeluaran Pemerintah (X3) sebagai variabel independen. Metode yang digunakan yaitu regresi linier berganda data panel. Data panel adalah diartikan penggabungan antara data cross setion dan data time series (Suliyanto, 2011). Regresi data panel pada penelitian ini menggunakan software e-views 9. Berikut adalah persamaan regresi linier berganda data panel yang digunakan dalam penelitian ini.

$Y_{i t}=a+\mathrm{b}_{1} \mathrm{X}_{1 \mathrm{it}}+\mathrm{b}_{2} \mathrm{X}_{2 \mathrm{it}}+\mathrm{b}_{3} \mathrm{X}_{3 \mathrm{it}}+\mathrm{e}$ 
Bambang Setijawan et al., Pengaruh Investasi, Tenaga Kerja Dan Pengeluaran Pemerintah Terhadap Pertumbuhan Ekonomi di Provinsi Jawa Tengah

Keterangan: $\mathrm{Y}=$ pertumbuhan ekonomi; $a=$ konstanta; $\mathrm{b}_{1}=$ koefisien regresi $\mathrm{X} 1 ; \mathrm{X}_{1}=$ investasi; $\mathrm{b}_{2}=\mathrm{koefisien}$ regresi $\mathrm{X} 2 ; \mathrm{X}_{2}=$ tenaga kerja; $\mathrm{b}_{3}=$ koefisien regresi $\mathrm{X} 3 ; \mathrm{X}_{3}=$ pengeluaran pemerintah; $\mathrm{i}=\mathrm{Jneis} \mathrm{Kabupaten} / \mathrm{Kota} ; \mathrm{t}=$ Waktu; e = Nilai residu/eror

Teknik analisis menggunakan estimasi regresi panel dilakukan tiga pendekatan model regresi antara lain (Basuki \& Prawoto, 2017) yaitu Common Effect Model (CEM), Fixed Effect Model (FEM) dan Random Effect Model (REM).Kemudian dalam pemilihan model untuk menemukan model yang cocok dalam regresi data panel perlu melakukan pemilihan metode estimasi yaitu Uji Chow, yang merupakan teknik pengujian yang dilaukan untuk memastikan pemilahan model yang tepat antara Model Common Effect dan Model Fixed Effect. Kedua Uji Hausman, pada pengujian ini dilakukan untuk mengestimasi dan menentukan model yang tepat dianatara Fixed Effect model atau Random Effect model. Ketiga Uji Lagrange Multiplier, pada pengujian ini dilakukan untuk menentukan model yang tepat untuk digunakan diantara common effect model atau random effect model. (Basuki \& Prawoto, 2017).

Untuk memastikan model yang diestimasi tidak menyimpang atau BLUE (Best Linear Unbiase Estimator), menurut Basuki \& Prawoto (2017) dilakukan uji asumsi klasik yang meliputi uji normalitas untuk mengetahui apakah data yang diolah berdistribusi normal atau tidak dan memenuhi standar statistik yang berhubungan dengan regresi. Uji autokorelasi untuk melihat ada tidaknya hubungan antara residual satu observasi dengan residual observasi lainnya. Uji heteroskedastisitas untuk melihat apakah residual dari model memiliki varians yang konstan atau tidak. Uji multikolinearitas untuk menguji apakah dalam model regresi ditemukan adanya korelasi antar variabel independen atau tidak.

\section{Hasil}

Berdasarkan Uji pemilihan model untuk mengetahui model manakah yang lebih tepat diantara Common Effect Model (CEM), Fixed Effect Model (FEM) dan Random Effect Model (FEM) dengan melakukan beberpa pengujian. Berdasarkan uji chow diperoleh nilai Probabilitas Cross-section Chi-Square sebesar 0,0000 yang berarti lebih kecil dari alpha $0,05(0,0000<0,05)$ sehingga model yang terpilih adalah Common Effect Model. Uji Hausman diperoleh nilai probabilitas Chi-Square sebesar 0,0000 lebih kecil dari $0,05(0,0000<0,05)$ sehingga model yang terpilih adalah Fixed Effect Model. Mengacu pada uji Chow dan uji Uji Hausman model yang terpilih adalah Common Effect Model, dengan demikian tidak perlu dilakukan uji Lagrange Multiplier. Hasil selanjutnya pada uji asumsi klasik yaitu pada uji normalitas hanya digunakan jika jumlah observasi penelitian kurang dari 30, untuk mengetahui error term mendekati distribusi normal. Jika jumlah observasi lebih dari 30 maka tidak perlu dilakukan uji normalitas (Basuki \& Prawoto, 2017). Pada penelitian ini jumlah observasinya adalah 210, maka uji normalitas tidak perlu dilakukan. Uji Autokorelasi diperoleh probabilitas $R$-square sebesar 0,5749 lebih kecil dari 0,05 maka dapat disimpulkan bahwa tidak terdapat masalah autokorelasi pada model tersebut. Uji heteroskedastisitas diperoleh hasil estimasi common effect model tanpa pembobotan (unweighted) dan common effect model dengan pebobotan (weighted) pada tabel di atas tidak terdapat perbedaan yang signikan. Nilai probabilitas F-satatistik dan t-statistik semuanya $<0,05$ sehingga dapat disimpulkan bahwa tidak terjadi heterosedaktisitas pada hasil common effet model. Uji Multikolinearitas diketahui bahwa koefisien korelasi kurng dari 0,8. Maka dapat disimpulkan bahwa tidak terjadi multikolinearitas pada hasil common effect model. Berikut tabel 1 yang menunjukkan ringkasan output regresi model common effect model.

Tabel 2

Regresi Data Panel Common Effect Model

\begin{tabular}{lrrrr}
\hline & Variable & Coeficient & Std. Error & \multicolumn{1}{c}{ t-Statistic } \\
\hline C & -11.39697 & 5.21300 .3 & -2.186258 & Prob. \\
Investasi & 0.071215 & 0.011947 & 5.960672 & 0.0302 \\
Tenaga Kerja & 1.235372 & 0.507519 & 2.434141 & 0.0160 \\
P. Pemerintah & 0.156114 & 0.022765 & 6.857681 & 0.0000 \\
\hline
\end{tabular}

Sumber: olahan data

Investasi berpengaruh signifikan dan positif terhadap pertumbuhan ekonomi di provinsi Jawa Tengah. Hasil penelitian ini sejalan dengan penelitian terdahulu yang dilakuan oleh Chidoko (2015), Rabnawas (2015), Williams, et al (2017), Prasetyawan, et al (2017), Ningsih \& Sari (2018), Tasrif, et al (2019) dan Hardiyanti, et al (2020). Investasi ditujukan untuk meningkatkan pertumbuhan ekonomi secara langsung maupun tidak langsung. Investasi pada penelitian ini menggunakan data penanaman modal dalam negeri. Berdasarkan tahun penelitan terlihat jumlah penanaman modal dalam negeri dari tahun 2014 hingga 2019 seluruh Kabupaten/Kota di Provinsi Jawa Tengah relatif mengalami peningkatan pertahunnya. Di Provinsi Jawa Tengah perekonomian tidak bisa lepas dari peranan investasi yang ditanamkan, dalam upaya pembangunan daerah Provinsi Jawa Tengah maka diperlukan investasi secara terus menerus meningkat dengan memperhatikan kemampuan yang dimiliki daerah tersendiri dan nasional. Dengan begitu maka nantinya akan menciptakan pertumbuhan ekonomi yang lebih baik. Tenaga kerja berpengaruh signifikan dan 
positif terhadap pertumbuhan ekonomi di provinsi Jawa Tengah. Hasil ini sejalan dengan penelitian terdahulu yantg dilakukan oleh Sari, et al (2016), williams, et al (2017), Rezki, et al (2018), Primalasari, et al (2019) dan Tasrif, et al (2019). Tenaga kerja yang semakin produktif akan meningkatkan jumlah barang dan jasa yang diproduksi, sehingga akan meningkatkan pertumbuhan ekonomi. Tenaga kerja pada penelitian ini menggunakan jumlah angkatan kerja yang sedang dalam usia produktif dan sedang giat mencari pekerjaan. Berdasarkan tahun penelitan terlihat jumlah tenaga kerja dari tahun 2014 hingga 2019 seluruh Kabupaten/Kota di Provinsi Jawa Tengah mengalami peningkatan pertahunnya. Dengan begitu dapat disimpulkan dengan semakin banyak jumlah tenaga kerja yang produktif serta terciptanya lapangan pekerjaan yang luas maka semakin tinggi pula tingkat outputnya, maka pertumbuhan ekonomi menuju kearah yang lebih baik (Purnomo, 2021).

Pengeluaran pemerintah berpengaruh signifikan dan positif terhadap pertumbuhan ekonomi di provinsi Jawa Tengah. Hasil penelitian ini sejalan dengan penelitian terdahulu yang dilakukan oleh Sari, et al (2016), Munzil, et al (2017), Rezki, et al (2018), Ichvani \& Sasana (2019), dan Nasution, (2020). Dalam konsep ekonomi makro pengeluaran pemerintah akan meningkatkan perekonomian nasional, jadi apabila pengeluaran pemerintah meningkat maka pertumbuhan ekonomi juga akan meningkat. Pengeluaran pemerintah dalam penelitian ini adalah total belanja pemerintah baik secara langsung maupun tidak langsung. Berdasarkan tahun penelitan terlihat total pengeluaran pemerintah yang dikeluarkan dari tahun 2014 hingga 2019 seluruh Kabupaten/Kota di Provinsi Jawa Tengah relatif terjadi peningkatan pertahunnya. Pemerintah di Provinsi Jawa Tengah sudah cukup baik dalam mengaloksikan anggaran biaya pada sektor - sektor yang mendorong peningkatan pertumbuhan ekonomi. Dengan meningkatnya pengeluaran pemerintah juga akan mempengaruhi konsumsi yang terjadi di masyarakat, sehingga nantinya mampu meningkatkan pertumbuhan ekonomi yang lebih baik.

\section{Simpulan}

Hasil penelitian menunjukkan bahwa investasi tenaga kerja dan pengeluaran pemerintah berpengaruh positif dan signifikan terhadap pertumbuhan ekonomi di Provinsi Jawa Tengah tahun 2014 - 2019. Penelitian ini memberikan rekomendasi kepada Pemerintah Provinsi Jawa Tengah dan Pemerintah Kabupaten/Kota untuk terus mempertahankan investor yang sudah masuk dengan memberikan pelayanan sesuai dengan perkembangan kebutuhan masing-masing serta memberikan insentif sehingga investor merasa nyaman menanamkan modalnya dan menarik calon-calon investor baru untuk bersedia membuka bisnis di Provinsi Jawa Tengah. Kemudian juga sebaiknya meningkatkan kembali lapangan pekerjaan, mengadakan proyek magang bagi calon tenag kerja, meningkatkan kesejahteraan tenaga kerja, dan meningkatkan kualitas tenaga kerja sehingga produktivitas tenaga kerja akan meningkat serta lebih meningkatkan dan memaksimalkan alokasi dana belanja pemerintah untuk sektor-sektor yang potensial sehingga nantinya akan akan meningkatkan Produk Domestik Regional Bruto (PDRB).

\section{Daftar Pustaka}

Astuti, W. A., Hidayat, M., \& Darwin, R. (2017). Pengaruh Investasi, Tenaga Kerja dan Pertumbuhan Penduduk Terhadap Pertumbuhan Ekonomi di Kabupaten Pelalawan. Jurnal Akuntansi Dan Ekonomika, 7(2), 141-147.

Badan Pusat Statistik Jawa Tengah. (2014) - (2020). Jawa Tengah Dalam Angka 2014. Jawa Tengah.

Bado, B. (2016). Analisis Belanja Modal, Investasi, Dan Tenaga Kerja Terhadap Pertumbuhan Ekonomi Sulawesi Selatan. Jurnal Ilmiah Econosains, 14(2), 34-42

Basuki, A. T., \& Prawoto, N. (2017). Analisis Regresi Dalam Penelitian Ekonomi \& Bisnis (Dilengkapi Aplikasi SPSS \& Eviews). Jakarta: PT Rajagrafindo Persada.

Chidoko, C., \& Sachirarwe, I. (2015). An Analysis of the Impact of Investment on Economic Growth in Zimbabwe. Review of Knowledge Economy, 2(2), 93-98.

Darwin, R., \& Hardilawati, W. L. (2018). Analisis Pertumbuhan Ekonomi dan Pengeluaran Pemerintah Terhadap Pegerakan Investasi Provinsi Riau. Jurnal Akuntansi Dan Ekonomika, 8(2), 190-197.

Dwiningwarni, S. S. (2011). Pengaruh Investasi, Tenaga Kerja Dan Pengeluaran Pemerintah Terhadap Pertumbuhan Ekonomi Di Propinsi Jawa Timur. Ekuitas: Jurnal Ekonomi Dan Keuangan, 15(4).

Ernita, D., Amar, S., \& Syofyan, E. (2013). Analisis Pertumbuhan Ekonomi, Investasi, dan Konsumsi di Indonesia. Jurnal Kajian Ekonomi, 1(2), 176-177.

Gani, I., \& Amalia, S. (2015). Aplikasi Statistik Untuk Penelitian Bidang Ekonomi Dan Sosial. Yogyakarta: Andi.

Ichvani, L. F., \& Sasana, H. (2019). Pengaruh Korupsi, Konsumsi, Pengeluaran Pemerintah Dan Keterbukaan Perdagangan Terhadap Pertumbuhan Ekonomi Di Asean 5. Jurnal REP (Riset Ekonomi Pembangunan) 4(1), 61-72.

Nasution, A. Z. (2020). Pengaruh Investasi Dan Pengeluaran Pemerintah Terhadap Pertumbuhan Ekonomi Serta Dampak Terhadap Pengangguran. Masters thesis, Universitas Islam Negeri Sumatera Utara.

Ningsih, D., \& Sari, S. I. (2018). Pengaruh Investasi Dan Tenaga Kerja Terhadap Pertumbuhan Ekonomi di Kota Batam. Jurnal Akuntansi Barelang, Universitas Putera Batam, 3(4), 21-31. 
Bambang Setijawan et al., Pengaruh Investasi, Tenaga Kerja Dan Pengeluaran Pemerintah Terhadap Pertumbuhan Ekonomi di Provinsi Jawa Tengah

Pangiuk, A. (2017). Pengaruh Investasi Dan Pengeluaran Pemerintah Terhadap Pertumbuhan Ekonomi Provinsi Jambi. Iltizam Journal Of Shariah Economic Research, 1(1), 1-20.

Pramono, S. A. D. (2014). Pengaruh Modal Sosial terhadap Kemiskinan Rumah Tangga. JEJAK Journal of Economics and Policy, 7(2), 109-120.

Primalasari, A., Indarti, I., Adnanti, W. A. (2019). Analisis Pertumbuhan Ekonomi Jawa Tengah Periode 2013 - 2017. Jurnal Ilmiah Aset, 21(2), 63-70.

Purnamasari, S. A., Rostin, R., \& Ernawati, E. (2017). Pengaruh Investasi Dan Tenaga Kerja Terhadap Pertumbuhan Ekonomi Di Provinsi Sulawesi Tenggara. Jurnal Progres Ekonomi Pembangunan (JPEP), 2(2), 1-14.

Purnomo, S. D. (2021). Analysis of Labor Absorption in Central Java Province. Ekonomis: Journal of Economics and Business, 5(1), 240-244.

Wulansari, D. A., Syaifuddin, S., \& Amzar, Y. V. (2016). Pengaruh pengeluaran pemerintah, inflasi dan angkatan kerja terhadap pertumbuhan ekonomi Indonesia. e-Jurnal Ekonomi Sumberdaya dan Lingkungan, 5(2), 23-43.

Sari, M., Syechalad, M. N., \& Majid, S. A. (2016). Pengaruh investasi, tenaga kerja dan pengeluaran pemerintah terhadap pertumbuhan ekonomi di Indonesia. Jurnal Ekonomi Dan Kebijakan Publik Indonesia, 3(2), 109115.

Sugiyono, S. (2017). Statistika untuk Penelitian. Bandung. Alfabeta.

Sukirno, S. (2013). Makro Ekonomi, Teori Pengantar. PT Raja Grafindo Persada. Jakarta.

Suliyanto, S. (2011). Ekonometrika Terapan: Teori Dan Aplikasi Dengan SPSS. . Yogyakarta: ANDI.

Tasrif, M., Rosnawintang, R., \& Rahim, M. (2019). Analisis Pengaruh Investasi Dan Tenaga Kerja Terhadap Pertumbuhan Ekonomi Antar Provinsi Di Indonesia. JPEP (Jurnal Progres Ekonomi Pembangunan), 4(2), 6780.

Prasetyawan, D. T., Hanim, A., \& Yuliati, L. (2017). Analisis Pengaruh Investasi dan Tenaga Kerja Terhadap Pertumbuhan Ekonomi Serta Hubungannya Terhadap Kemiskinan di Provinsi Jawa Timur. Jurnal Ekuilibrium, 1(1), 45-50. 